Article

\title{
A New Insight into Shale-Gas Accumulation Conditions and Favorable Areas of the Xinkailing Formation in the Wuning Area, North-West Jiangxi, China
}

\author{
Shangru Li ${ }^{1,2}$, Li Zeng ${ }^{1,2}$, Zhongpeng Wang ${ }^{1,2, *}$, Jinchuan Zhang ${ }^{3}$ and Dong Ma ${ }^{4, *}$ \\ 1 Jiangxi Geo-Engineering (Group) Corporation, Nanchang 330001, China; ShangruLi@126.com (S.L.); \\ m18107085364@163.com (L.Z.) \\ 2 GanZhongNan Institute of Geology and Mineral Exploration, Nanchang 330001, China \\ 3 School of Energy Resources, China University of Geosciences, Beijing 100089, China; zhangjc@cugb.edu.cn \\ 4 School of Petroleum Engineering, Yangtze Univeristy, Wuhan 430100, China \\ * $\quad$ Correspondence: spgwzp@163.com (Z.W.); madong@yangtzeu.edu.cn (D.M.); Tel.: +86-157-2766-7223 (Z.W.)
}

Received: 27 November 2017; Accepted: 19 December 2017; Published: 21 December 2017

\begin{abstract}
In north-west Jiangxi, China, most shale-gas exploration has been focused on the Lower Cambrian Hetang and Guanyintang formations, whereas the Upper Ordovician Xinkailing formation shale has been ignored for years due to heavy weathering. This study systematically analyzed gas source conditions, reservoir conditions and gas-bearing ability in order to reveal the shale-gas accumulation conditions of the Xinkailing formation. The results show that the Xinkailing formation is characterized by thick deposition of black shale (10-80 m), high organic content (with total organic carbon between $1.18 \%$ and $3.11 \%$, on average greater than $2 \%$ ), relatively moderate thermal evolution (with vitrinite reflectance between $2.83 \%$ and $3.21 \%$ ), high brittle-mineral content (greater than $40 \%$ ), abundant nanopores and micro-fractures, very good adsorption ability (adsorption content between $2.12 \mathrm{~m}^{3} / \mathrm{t}$ and $3.47 \mathrm{~m}^{3} / \mathrm{t}$, on average about $2.50 \mathrm{~m}^{3} / \mathrm{t}$ ), and strong sealing ability in the underlying and overlying layers, all of which favor the generation and accumulation of shale gas. The Wuning-Lixi and Jinkou-Zhelin areas of the Xinkailing formation were selected as the most realistic and favorable targets for shale-gas exploration and exploitation. In conclusion, the Wuning area has great potential and can provide a breakthrough in shale gas with further investigation.
\end{abstract}

Keywords: north-west Jiangxi; Wuning area; Xinkailing formation shale; gas-generating conditions; reservoir conditions; gas-bearing potential; favorable area

\section{Introduction}

Shale-gas exploration and development have seen enormous commercial success in the United States over the past 10 years [1-3], altering its status from an oil and gas importing country to an exporting one. Inspired by that, shale gas research has been conducted throughout marine, transitional and continental strata in China recently [4-7]. Significant progress has been made in shale gas exploration and exploitation in the Upper Yangtze Platform, most notably in the Upper Ordovician Wufeng formation-Lower Silurian Longmaxi formation [8,9].

With the growing demand for national energy production, several studies have been carried out concerning Lower Paleozoic black shale in the middle-upper Yangtze area [10-13]. Most of these studies have focused on the two high-quality formations [14-18]: the Upper Ordovician Wufeng formation/Lower Silurian Longmaxi formation (collectively known as the Longmaxi formation) and the Lower Cambrian Niutitang formation (including the Shuijingtuo formation or Qiongzhusi formation, collectively known as the Niutitang formation). It is worth noting that both formations 
are made up of high-quality source rock deposits. Due to the influence of its sedimentary age and sub-surface depth, the Longmaxi formation was better developed than the Niutitang formation [19], and commercial gas production has been achieved in the areas of Fuling, Weiyuan-Changning, Zhaotong, and Pengshui [20]. The parameters, including thickness, TOC (total organic carbon), $R_{o}$ (referring to vitrinite reflectance), reservoir conditions and so on, have been testified to be the key factors of accumulation conditions and favorable areas of shale gas [17].

Due to their similar tectonic dynamics [21], the lower Yangtze and middle-upper Yangtze areas also share similar sedimentary-tectonic evolution and shale-layer development. Previous studies concerning shale formation with rich organic matter in north-west Jiangxi focused on the shale development characteristics of the Lower Cambrian Hetang formation and the Guanyintang formation [22,23]. However, there are few published accounts that describe the hydrocarbon source-rock potential of the Upper Ordovician Xinkailing formation. Geochemical analysis data of outcrop samples from section PM1 has shown that the Xinkailing shale is severely weathered and not suitable for exploitation (as shown in Figure 1A). Accordingly, it has been ignored for years.

However, the core samples, which were acquired from a water well beside the section PM1, revealed excellent shale development characteristics (as shown in Figure 1B) and an enormous potential for shale gas resources in the Xinkailing formation. Jiangxi Province is characterized by a continuous deficit in oil and gas. If a breakthrough can be made in the extraction of Xinkailing shale, it may change the energy structure of the province.

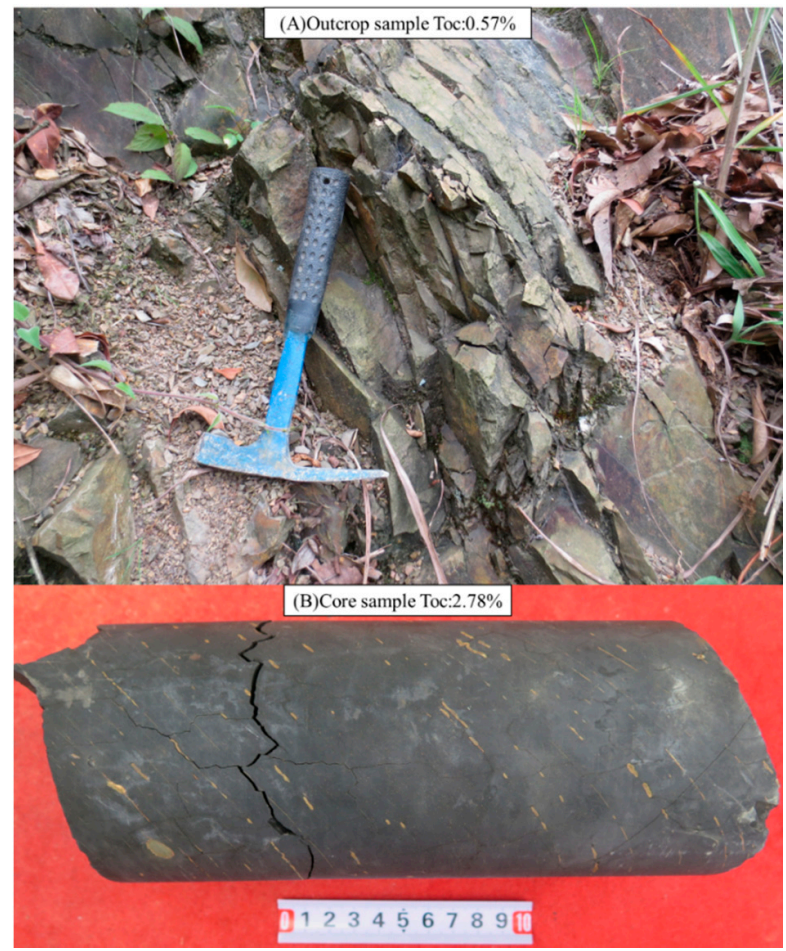

Figure 1. (A) The characteristics of an outcrop sample of Xinkailing-formation shale; (B) the characteristics of a core sample of Xinkailing-formation shale. (The location of outcrop sample and core sample can be seen in Figure 2).

For this study, the thickness of Xinkailing shale in the middle of the Xiuwu Basin was investigated using a measured profile. Then, features such as organic chemistry, mineral composition, reservoir properties, and pore distribution and structure were analyzed using laboratory testing of shale samples from the water well. The primary objectives of this paper are to: (1) characterize the hydrocarbon generation conditions of the Xinkailing shale; (2) determine whether the reservoir is suitable for shale gas; and (3) discuss the gas-bearing potential and favorable distribution areas within the Xinkailing formation. 


\section{Geological Setting}

\subsection{Overview}

The study area is situated in the eastern Xiuwu Basin, Lower Yangtze Plate. The administrative regions are mainly comprised of Wuning county, in the north-west area of Jiangxi province (as shown in Figure 2a). The formation and evolution of the area can be broken down into four main stages (as shown in Figure 2b): (1) the Mesoproterozoic-Silurian $\left(\mathrm{Pt}_{2}-\mathrm{S}\right)$ basal formation and deformation stage; (2) the Devonian-middle Triassic (D- $\left.\mathrm{T}_{2}\right)$ passive continental margin stage; (3) the Late Triassic-Cretaceous $\left(\mathrm{T}_{3}-\mathrm{K}\right)$ intense orogeny stage; and (4) the Jurassic-Quaternary $(\mathrm{J}-\mathrm{Q})$ down-faulted red basin stage. Due to tectonic compression during the $\mathrm{T}_{3}-\mathrm{K}$, folds and faults are well developed in the study area (as shown in Figure 2c). The folds are present in a primarily east-west syncline. The faults in the study area are primarily detachment faults and normal faults, both of which appear in an east-west trend. The Ordovician-silurian shale tectonic deformation was weaker than the Cambrian shale formation [24].

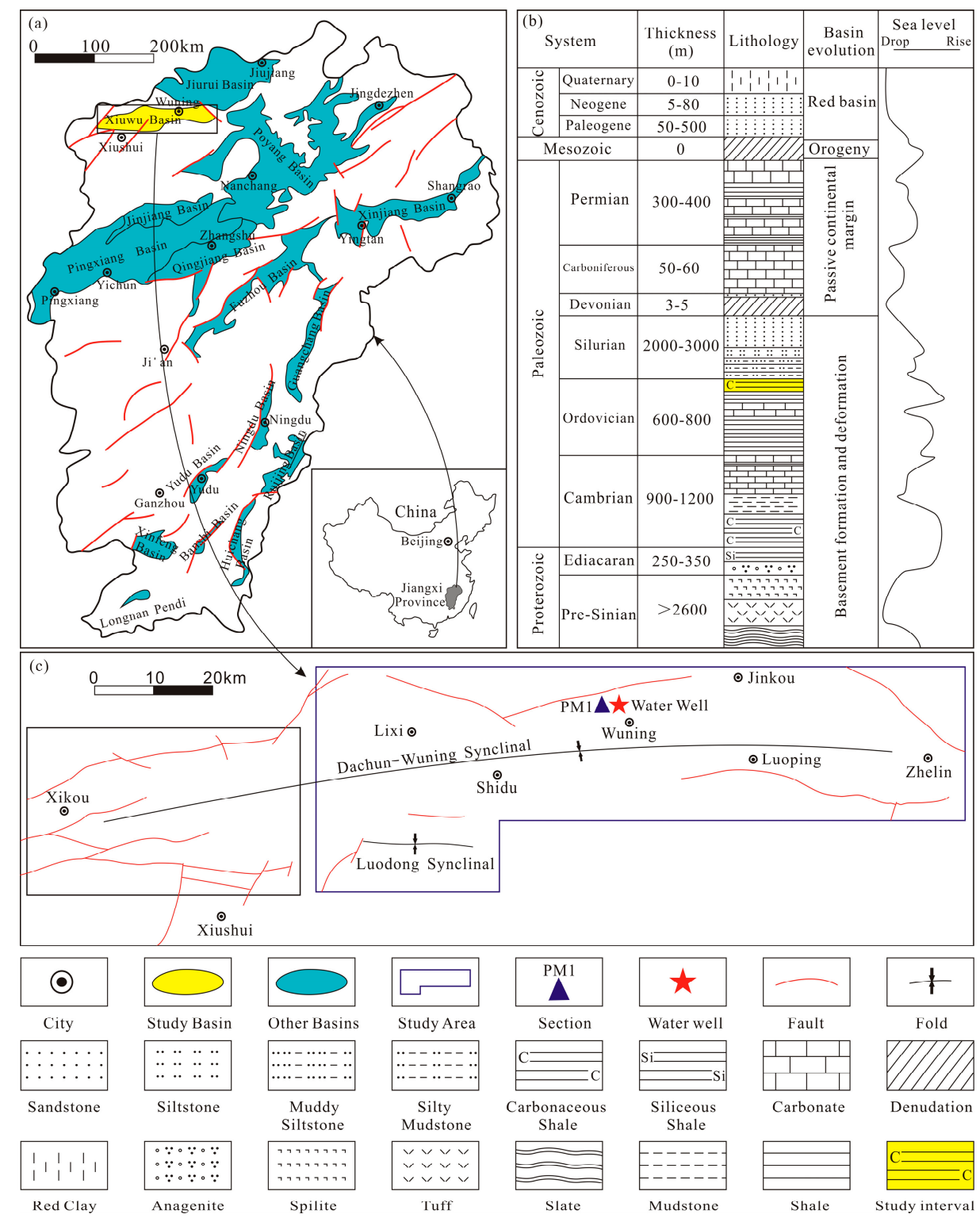

Figure 2. (a) The location of Xiuwu Basin, Jiangxi Province, China; (b) the structural characteristics of the study area and the site of the water well; (c) schematic diagram showing the stratigraphy and basin evolution of Xiuwu Basin. 


\subsection{Shale-Distribution Characteristics}

The organic-rich shale of the Xinkailing formation was developed in a transgressive system tract environment, which is primarily made up of deep-water sand-mud shelf sediments and a carbon-mud shelf. The strata profile measurements of the Xinkailing formation was conducted in section PM1 (the location of which as shown in Figure 2), which revealed both the top and bottom boundary of the Xinkailing formation (as shown in Figure 3).

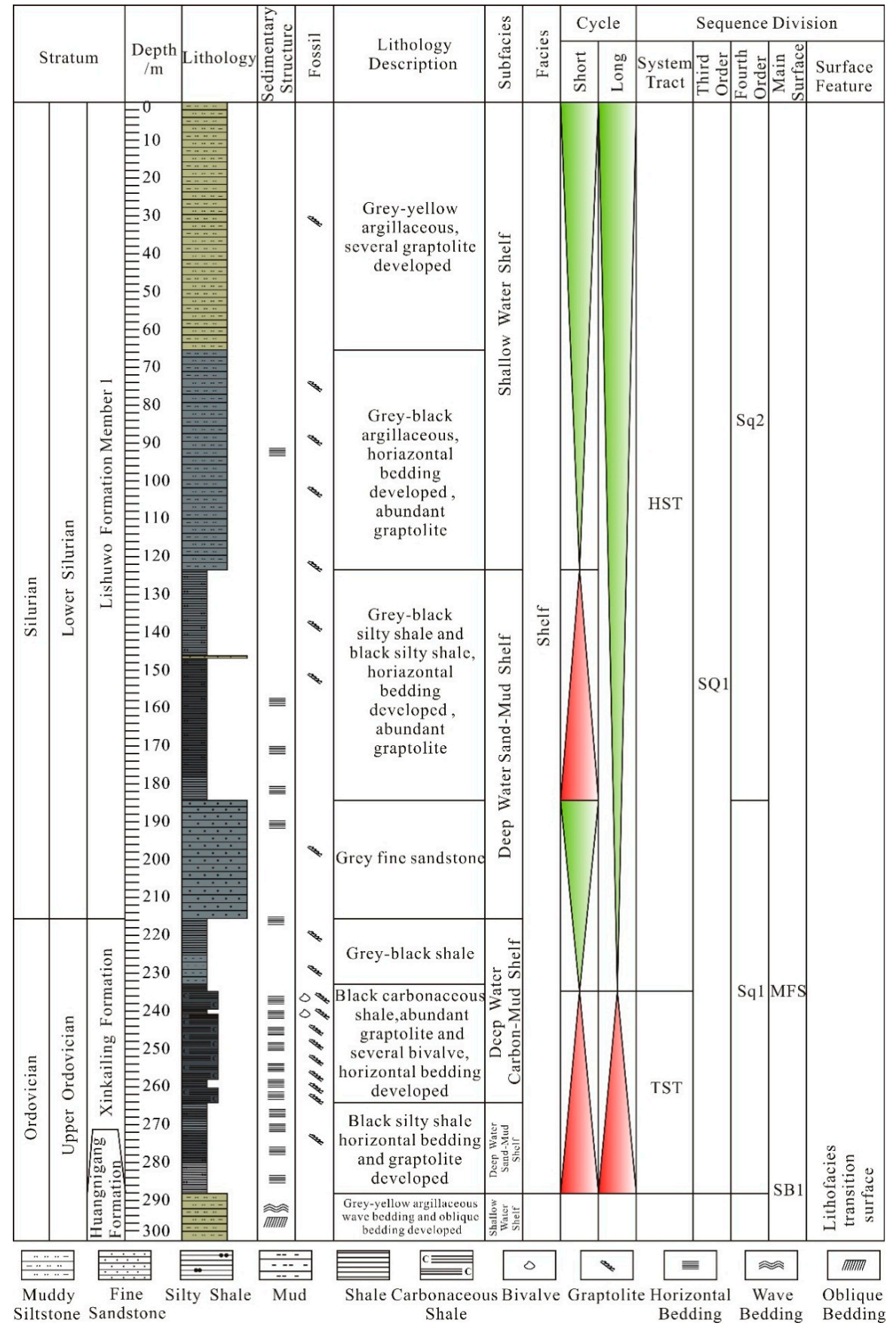

Figure 3. Xinkailing-Lishuwo formation sedimentary and stratigraphic section from PM1.

Above the top surface, silty mudstone from the Lishuwo formation was found, and beneath the bottom surface was argillaceous shale from the Huangnigang formation, both of which are characterized by a powerful sealing capacity. The lithology of the Xinkailing formation changed 
vertically. In the lower section, black shale dominated with intermittent bedding of grey-black silty shale, and this horizontal bedding was well developed with few graptolites. In the middle section, black calcareous shale developed with numerous graptolites and the horizontal bedding was clearly visible. In the upper section, highly-weathered grey black shale appeared with a pale-yellow surface, and the presence of graptolites decreased as depth from the surface decreased. The total thickness of these three members was $72.56 \mathrm{~m}$. Fortunately, a water well (drilling began in the lower section) nearby PM1 revealed $18 \mathrm{~m}$ of black shale with sustained thickness and developed pyrite, which was a positive signal of un-weathered Xinkailing-formation shale. This suggested that Xinkailing formation shale developed in a deep-water shelf with a strong anoxic environment, which is favorable for the preservation of organic matter $[25,26]$. The lithology of the Xinkailing formation was mainly comprised of black mud shale and carbonaceous shale. In the whole area, the thickness of organic-rich shale varies from $10 \mathrm{~m}$ to $80 \mathrm{~m}$ (with an average thickness of $50 \mathrm{~m}$ ). The sub-surface depth is controlled by the tectonic distribution and in the Wuning-Lixi area is relatively deep (ranging from $500 \mathrm{~m}$ to $3000 \mathrm{~m}$ ), while the depth in the Jinkou-Zhelin area is generally less than $1500 \mathrm{~m}$.

\section{Data and Methodology}

Thirty core samples and 33 outcrop samples were taken from the water well $18 \mathrm{~m}$ shale and section PM1 $75 \mathrm{~m}$ shale, respectively. With regard to these samples, relevant experiments were conducted and abundant data gathered. Source-rock data (including organic matter type, total organic carbon, vitrinite reflectance) were obtained from 30 core samples and 33 outcrop samples and reservoir data (including mineral composition, porosity and permeability, scanning electron microscope (SEM) (FEI Quanta200F, FEI, Hillsboro, OR, USA), Brunauer-Emmett-Teller (BET) specific surface area and isothermal adsorption) were obtained from 30 core samples. The types of organic matter were divided using the following criteria [13]: type I kerogen carbon isotopes are less than $-29 \%$ organic matter, while type II are greater than $-29 \%$. The $R_{o}$ values were calculated using Equation (1) [27]:

$$
R_{o}=0.3195+0.6790 \times R_{b}
$$

where $R_{o}$ refers to vitrinite reflectance (\%) and $R_{b}$ refers to bitumen reflectance (\%).

In addition, illite crystallinity could also reflect high levels of evolution for marine shale maturity [28]. Source-rock data (organic matter type, total organic carbon, and vitrinite reflectance) and reservoir data (mineral composition, porosity and permeability, BET specific surface area, and isothermal adsorption) were provided by the Keyuan Engineering Testing Center of Sichuan Province. SEM observations were conducted in the China Petroleum University, Beijing.

\section{Results}

\subsection{Hydrocarbon-Generation Conditions}

Based on the criteria of Liang et al. [13], samples from the Xinkailing formation in Wuning were analyzed using the kerogen isotope analysis method to determine their carbon isotope percentage (as shown in Figure 4). Results range from $-30.67 \%$ to $27.34 \%$ with an average value of $-29.03 \%$. For that reason, the main types of organic matter were classified into type I and type II.

Values for total organic carbon content of shale with commercial potential are generally more than $2 \%$ [29]. Statistical data analysis of 30 core samples and 33 outcrop samples showed that the total organic carbon content of the core samples ranged from $1.18 \%$ to $3.11 \%$, with an average value $2.11 \%$ (as shown in Figure 5). The majority of these samples were greater than $2 \%$, representing resource rock with good potential, while the TOC content for the outcrop samples ranged from $0.1 \%$ to $1.21 \%$, with an average value of $0.4 \%$. The majority of these samples were less than $1 \%$, representing resource rock with low potential. Comparison between core samples and outcrop samples demonstrated that the shale outcrops are easily weathered, resulting in lower total organic carbon content. Consequently, the outcrop samples do not accurately represent the actual organic matter abundance in the Wuning area. 
The $R_{o}$ values for 10 core samples from the Xinkailing formation shale were calculated based on the method of Feng et al. [27], and values ranged from $2.83 \%$ to $3.21 \%$, with an average value of $2.99 \%$. Illite crystallinity values ranged from 0.35 to 0.37 , with an average of 0.356 , which implies that the Xinkailing formation has been beneath the surface for a long time at a very low diagenetic stage. Generally speaking, the analyses of shale samples indicated that the degrees of evolution for the Xinkailing formation in Wuning were relatively high and the thermal evolution of the Xinkailing shale occurred during the early-middle stage of over-maturity [30,31], with dry gas predominating.

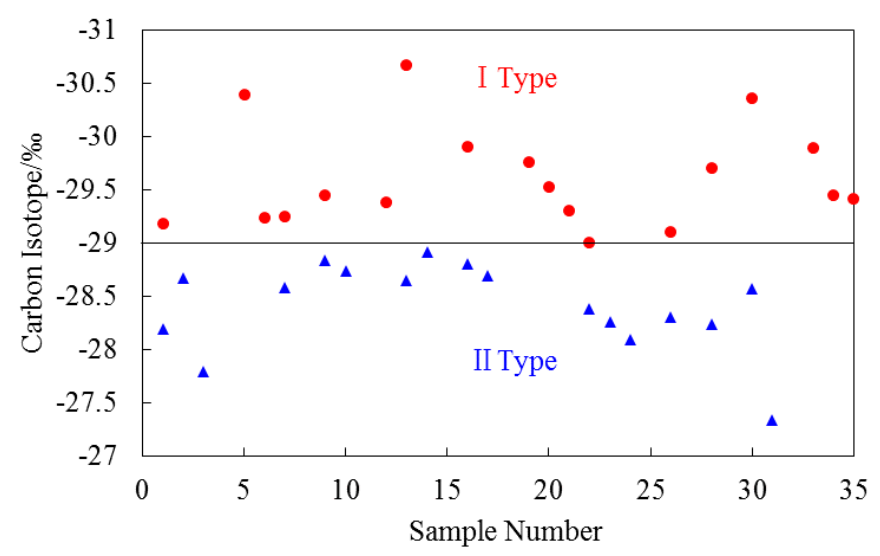

Figure 4. Carbon isotope variation of Xinkailing-formation shale samples in Wuning.

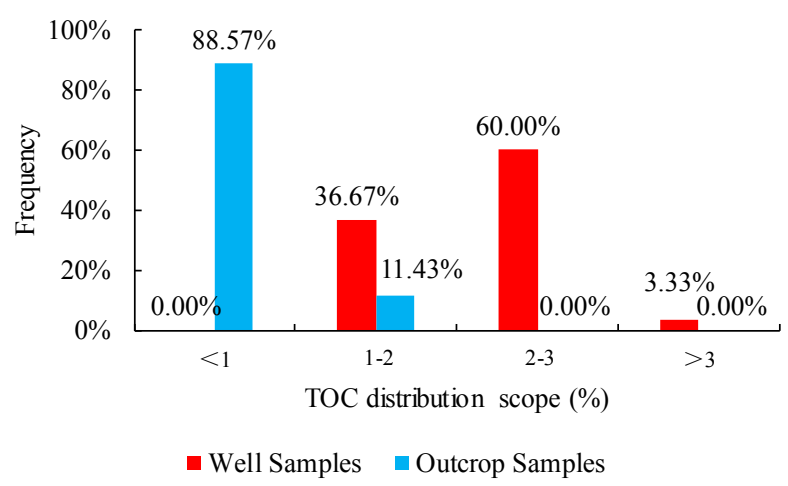

Figure 5. The total organic carbon comparison between well samples and outcrop samples in Wuning.

These three geochemical research results, which found that the shale organic matter type was optimum, the organic matter carbon content met good source rock conditions, and maturity remained relatively moderate, imply that the Xinkailing formation possesses excellent conditions for hydrocarbon generation. Comparisons of the organic geochemical test results between Xinkailing-formation black shale in Wuning area and lower Paleozoic shale in the middle-upper Yangtze area were conducted (as shown in Table 1), with results showing that Xinkailing formation shale has excellent gas-resource potential with similar characteristics.

Table 1. Comparison of the organic geochemical parameters between the Xinkailing-formation shale in Wuning and the Lower Paleozoic-formation shale in middle-upper Yangtze area. (Data from [17,32-34]).

\begin{tabular}{clccc}
\hline Area & Formation & Organic Matter Type & TOC (\%) & $\boldsymbol{R}_{\boldsymbol{o}} \mathbf{( \% )}$ \\
\hline Wuning & Xinkailing & I, II & $1.18-3.11$ & $2.83-3.21$ \\
Weiyuan-Rongxian & Longmaxi & I, II $_{1}$ & $1.09-6.51$ & $2.41-2.64$ \\
Fuling & & I & $1.04-5.89$ & $2.42-2.8$ \\
Jingyan-Qianwei & \multirow{2}{*}{ Qiongzhushi } & I & $1.15-3.55 / 1.87$ & $2.64-3.0$ \\
Weiyuan & & I & $2.0-4.2$ & $2.8-3.6$ \\
\hline
\end{tabular}




\subsection{Reservoir Conditions}

\subsubsection{Permeability and Porosity}

Porosity and permeability test results for Xinkailing-formation black shale revealed that the porosity of the samples ranged from $1.10 \%$ to $1.22 \%$, with an average value of $1.16 \%$, and the permeability of the samples ranged from $0.000445 \mathrm{md}$ to $0.001297 \mathrm{md}$, with an average of $0.000872 \mathrm{md}$. This means that both overall porosity and permeability are extremely low. Comparison of the physical characteristics of the Xinkailing formation black shale in the Wuning area and the lower Paleozoic shale in the middle-upper Yangtze area showed that low porosity and permeability are general characteristics of shale reservoirs (as shown in Figure 6) [35].

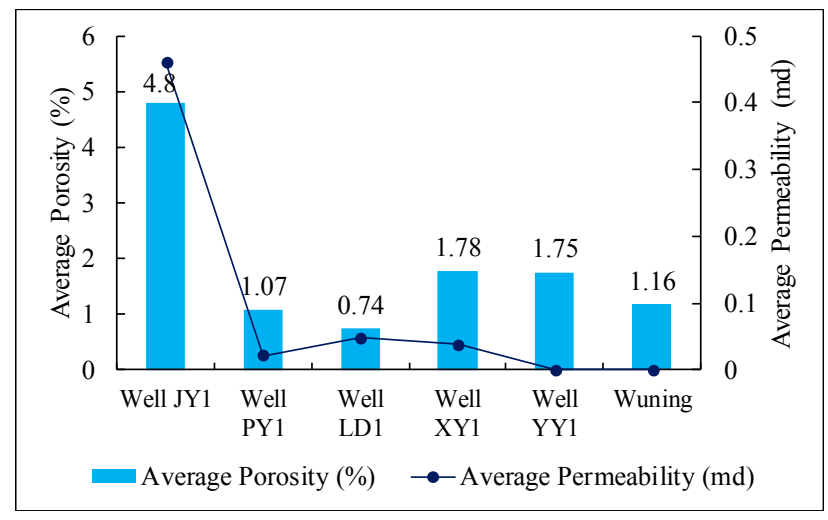

Figure 6. Comparison of the porosity and permeability between the Xinkailing-formation shale in Wuning and the Longmaxi-formation shale in the middle-upper Yangtze area.

\subsubsection{Reservoir Storage-Space Types}

Based on the core observations and SEM, the reservoir space types were also studied. At the macro level, the fracture types of the Xinkailing formation in Wuning are dominated by structural fractures and non-structural fractures. Structural fractures are the main fracture type of the Xinkailing formation in Wuning, such as vertical shearing cracks (as shown in Figure 7a) with straight seams and no fill. Non-structural fractures take second place; including interlayer lamellation seams and diagenetic shrinkage joints (as shown in Figure $7 \mathrm{~b}$ ). Diagenetic shrinkage joints are generally found in shale with high silicon content, formed by a shrinkage effect due to chemical changes during diagenesis. Additionally, vertical shearing fractures and interlayer lamellation seams could form abundant reticular fracture systems (as shown in Figure 7c), which could greatly enhance the reservoir space and permeability, forming crucial pathways for shale gas migration from the source to the reservoir [17,36,37].

At the micro level, Xinkailing-formation shale included four types: pores (cracks) between clay minerals, intergranular dissolution pores, pores between minerals, and organic matter pores. Pores (cracks) between clay minerals are about $1 \mu \mathrm{m}$ in size, dominated by micro fractures in the mineral edges (as shown in Figure 7d). Intergranular dissolution pores are relatively large, ranging from $1 \mu \mathrm{m}$ to $20 \mu \mathrm{m}$ (as shown in Figure 7e). Pores between minerals are mainly composed of pyrite intergranular nanometer pores, whose apertures range from $20 \mathrm{~nm}$ to $200 \mathrm{~nm}$ (as shown in Figure 7f). The diameters of the organic matter pores range from $2 \mathrm{~nm}$ to $100 \mathrm{~nm}$, featuring irregular striping or a honeycomb irregular elliptical shape (as shown in Figure 7g-i). Different pore types and apertures have different contributions to and effects on reservoir capacity and shale-gas production [36,38,39]. Therefore, fractures and micro-pores were greatly developed in the Xinkailing formation of Wuning, indicating that the Xinkailing-formation shale had abundant reservoir-space types and excellent reservoir conditions. 


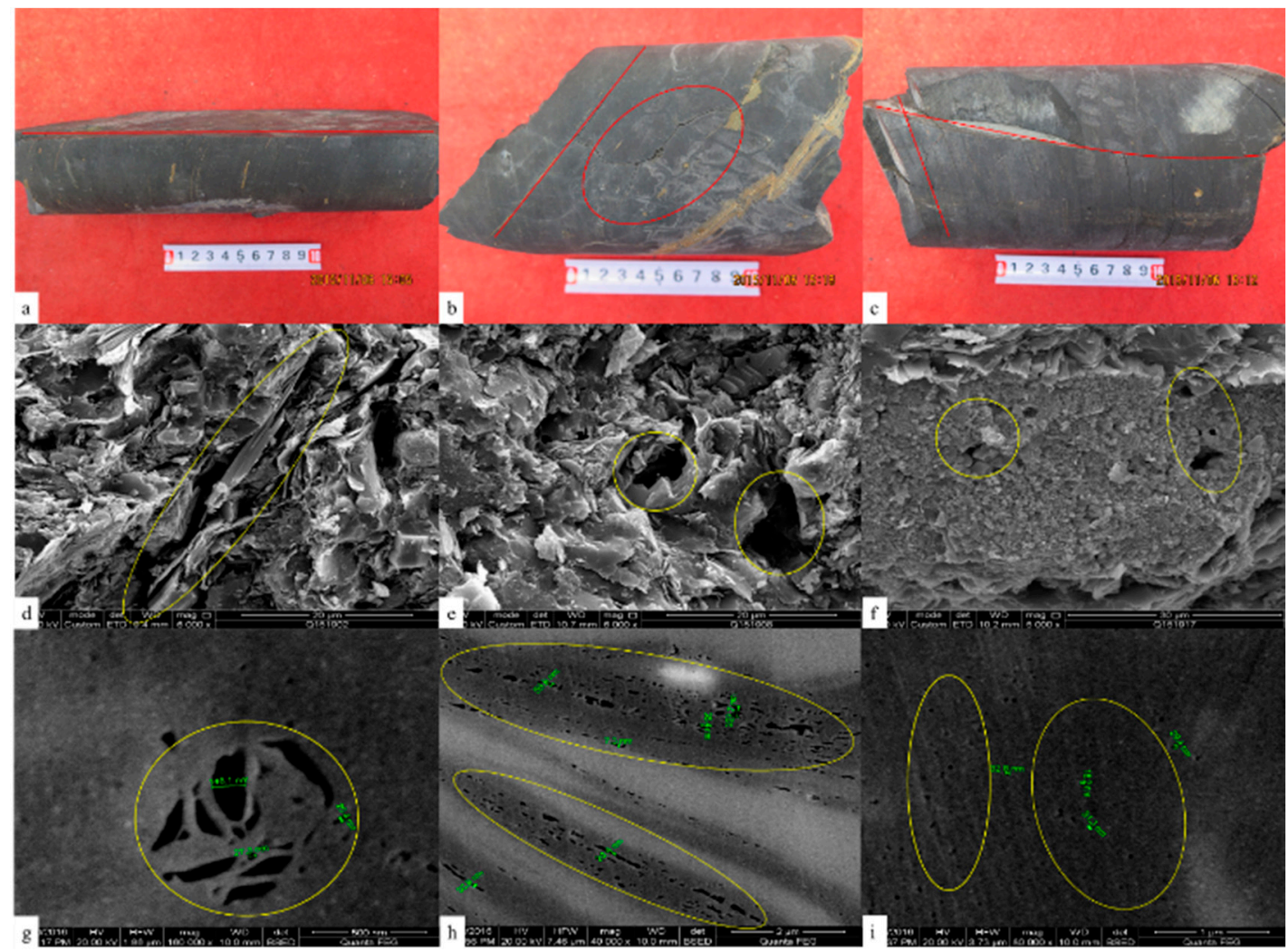

Figure 7. The reservoir storage-space types of Xinkailing shale in Wuning: (a) vertical shearing crack; (b) diagenetic shrinkage joint and interlayer lamellation seam; (c) vertical shearing crack and interlayer lamellation seam; (d) pore (crack) between clay minerals; (e) intergranular dissolution pore; (f) pyrite intergranular pore; (g) organic matter pore; (h) organic matter pore; (i) organic matter pore.

\subsubsection{Pore-Structure Characteristics}

Figure 8a-d shows the $\mathrm{N}_{2}$ adsorption-desorption isotherms of four of the Xinkailing shale samples. from Figure $8 \mathrm{a}-\mathrm{d}$, It can be observed that the $\mathrm{N}_{2}$ adsorption-desorption isotherms of the shale samples belong to the type IV isotherm (isotherm with a hysteresis loop) according to the International Union of Pure and Applied Chemistry (IUPAC) classification [40], indicating that the shale samples contain both mesopores (2-50 nm) [41] and macropores (>50 nm).

Analysis revealed that the BET specific surfaces values range from $15.69 \mathrm{~m}^{2} / \mathrm{g}$ to $20.41 \mathrm{~m}^{2} / \mathrm{g}$ (average: $17.83 \mathrm{~m}^{2} / \mathrm{g}$ ). The central radii of the pores range from $9.27 \mathrm{~nm}$ to $11.36 \mathrm{~nm}$, with an average of $6.8 \mathrm{~nm}$. The total pore volume of the Xinkailing shale varies from $20.8 \times 10^{-3} \mathrm{~cm}^{3} / \mathrm{g}$ to $30.5 \times 10^{-3} \mathrm{~cm}^{3} / \mathrm{g}$ (average: $\left.25.92 \times 10^{-3} \mathrm{~cm}^{3} / \mathrm{g}\right)$. The micro-pore $(<2 \mathrm{~nm})$ [41] volume of the Xinkailing shale ranges from $0.36 \times 10^{-3} \mathrm{~cm}^{3} / \mathrm{g}$ to $0.46 \times 10^{-3} \mathrm{~cm}^{3} / \mathrm{g}$ (average: $0.42 \times 10^{-3} \mathrm{~cm}^{3} / \mathrm{g}$ ); the meso-pore (2-50 nm) volume ranges from $11.6 \times 10^{-3} \mathrm{~cm}^{3} / \mathrm{g}$ to $16.8 \times 10^{-3} \mathrm{~cm}^{3} / \mathrm{g}$ (average: $13.85 \times 10^{-3} \mathrm{~cm}^{3} / \mathrm{g}$ ); and the macro-pore (>50 nm) volume ranges from $8.6 \times 10^{-3} \mathrm{~cm}^{3} / \mathrm{g}$ to $13.3 \times 10^{-3} \mathrm{~cm}^{3} / \mathrm{g}$ (average: $11.64 \times 10^{-3} \mathrm{~cm}^{3} / \mathrm{g}$ ) (as shown in Figure 8e-h). The percentages of micro-pores, meso-pores, and macro-pores are 1.63, 53.44 and $44.93 \%$, respectively, implying that meso-pores and macro-pores predominate among the Xinkailing shale.

Additionally, nanometer-scale spatial ordering occurs in the meso-pore-macro-pore range for all the samples, which may be associated with the organic matter pores and pores (cracks) between clay minerals $[42,43]$. 

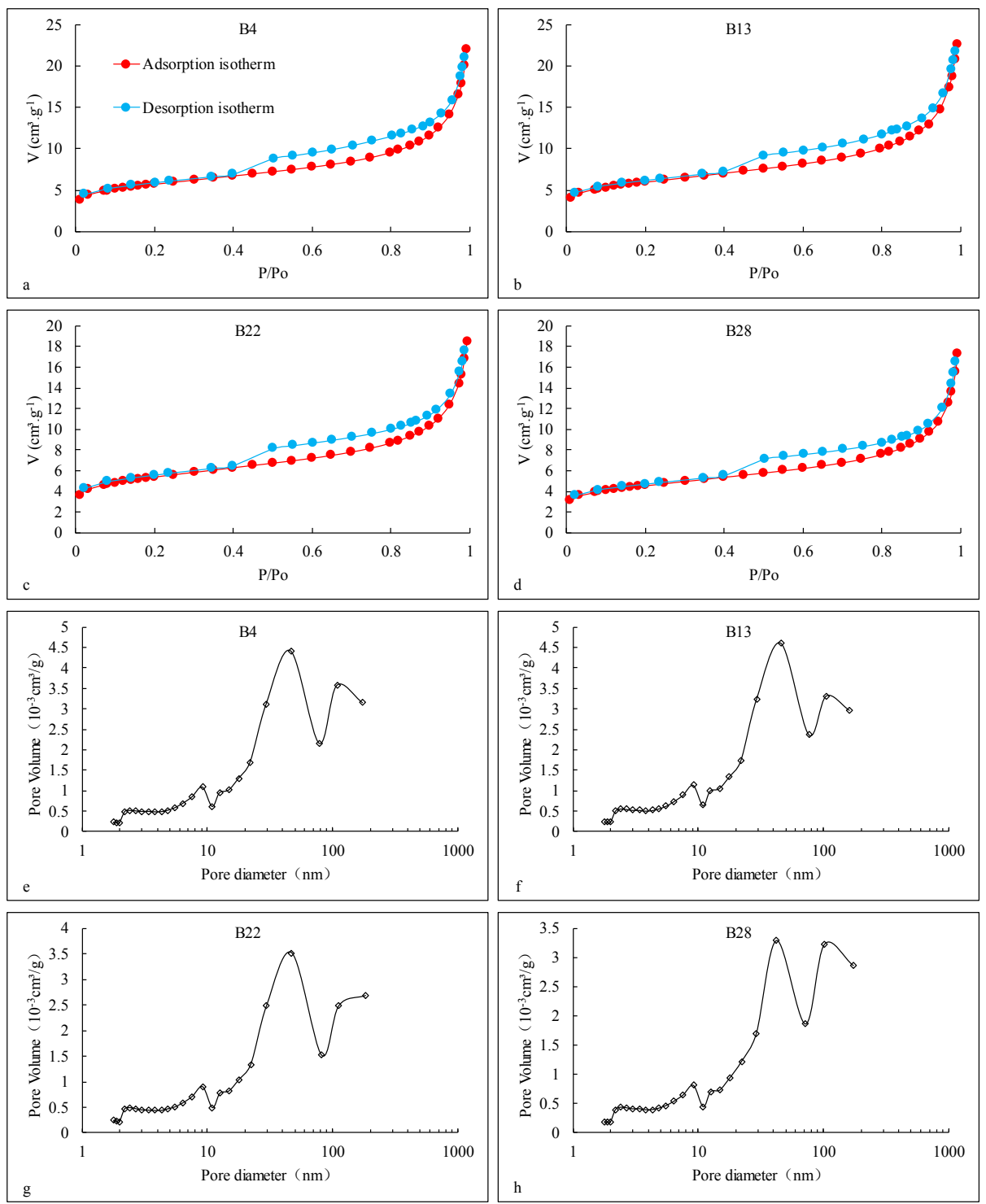

Figure 8. (a-d) Low-pressure $\mathrm{N}_{2}$ adsorption-desorption isotherms of four of the Xinkailing shale samples; (e-h) representative pore-size distribution from the studied samples.

\subsubsection{Mineral Composition and Lithofacies}

The Upper Ordovician Xinkailing shale-formation lithology is mainly comprised of black carbonaceous shale with abundant interlayer lamellation seams and layered pyrite (as shown in Figure 7a-c). X-ray sampling of whole-rock mineral content found that the mineral composition of Xinkailing-formation shale is dominated by brittle minerals and clay minerals (as shown in Figure 9a). In addition, pyrite developed throughout the formation.

The clay mineral content ranges from $32 \%$ to $46 \%$ (average: $39.66 \%$ ); the quartz content ranges from $32 \%$ to $46 \%$ (average: $39.46 \%$ ); the feldspar content ranges from $10 \%$ to $22 \%$ (average: $15.76 \%$ ); the carbonate mineral content ranges from $0 \%$ to $9 \%$ (average: $0.83 \%$ ); the siderite content ranges from $1 \%$ to $3 \%$ (average: $1.33 \%$ ); and the pyrite content ranges from 1 to $12 \%$ (average: $2.83 \%$ ). The brittle mineral (including quartz, feldspar, and carbonate) content ranges from $51 \%$ to $64 \%$ (average: $56.06 \%$ ) (as shown in Figure 9a). Results from the clay minerals' analysis showed that clay minerals in the Xinkailing formation contain few chlorites, kaolinite, and illite-montmorillonite mixed-layers, and are dominated by illite. The illite content ranges from 73\% to 97\% (average: 85\%) (as shown in Figure 9b). The mineral composition is closely related to high thermal evolution and diagenesis. 

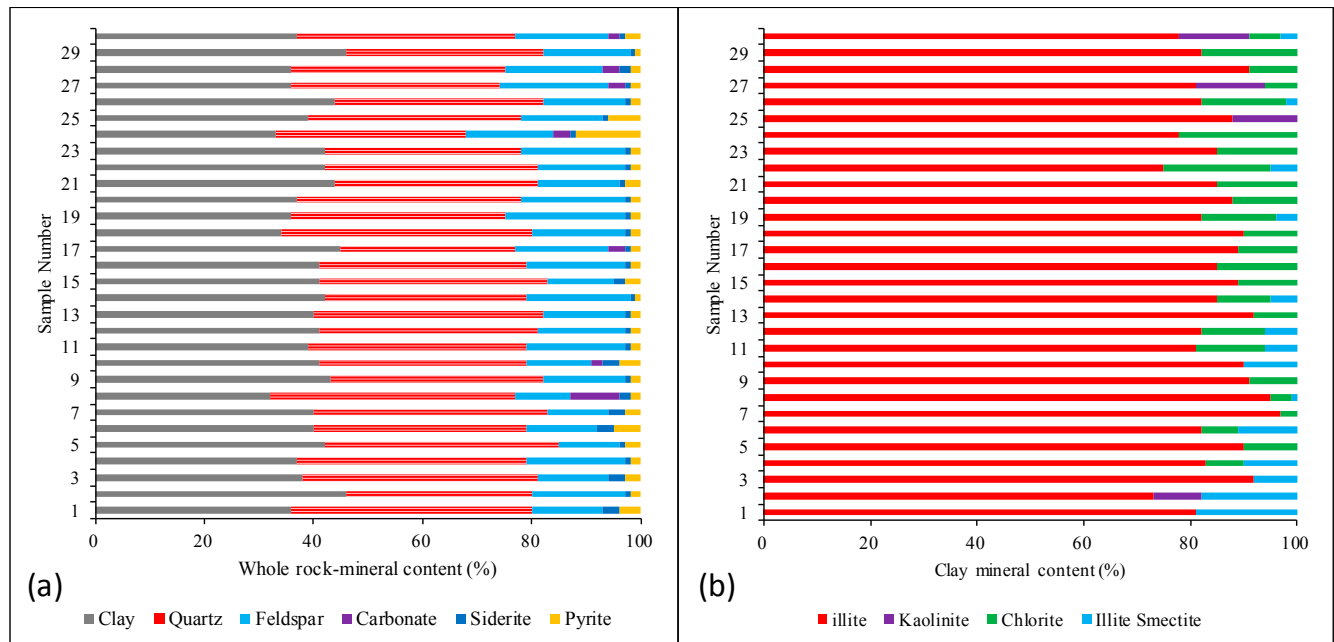

Figure 9. (a) The total rock mineral composition of the Xinkailing shale in Wuning; (b) the clay mineral composition of the Xinkailing shale.

Research has classified the shale in the Fuling area into four lithofacies (major classes) and 16 lithofacies (minor classes) [44] based on a 3-end-mumber diagram analysis of the silicon minerals, carbonate minerals, and clay minerals, and has found that mixed siliceous shale and clay-rich siliceous shale were most conducive to formation of lithofacies. Applying the 3-end-mumber diagram analysis to Xinkailing-formation shale, results showed that clay-rich siliceous shale contained most lithofacies (as shown in Figure 10). Above all, Xinkailing-formation shale is characterized by a high brittleness index and can easily be fractured.

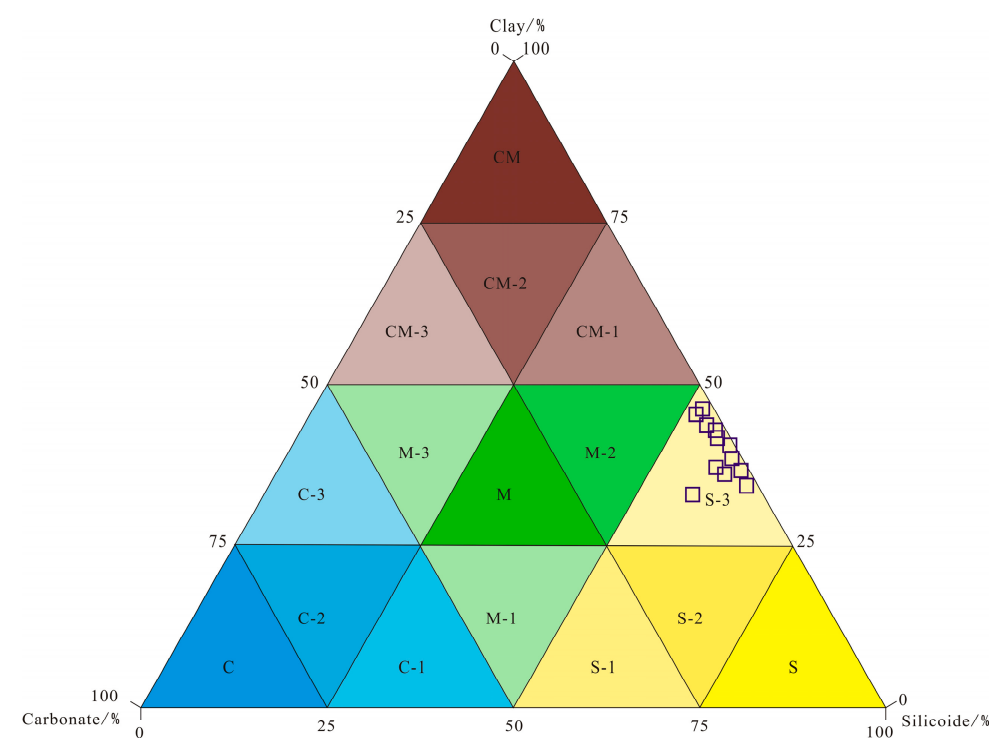

Figure 10. The ternary diagram of mineral composition for dividing lithofacies. S: siliceous shale lithofacies; S-1: calcarenite-rich siliceous shale lithofacies; S-2: mixed siliceous shale lithofacies; S-3: clay-rich siliceous shale lithofacies; CM: argillaceous shale lithofacies; CM-1: silica-rich argillaceous shale lithofacies; CM-2: mixed argillaceous shale lithofacies; CM-3: calcarenite-rich argillaceous shale lithofacies, C: calcareous shale lithofacies; C-1: silica-rich calcareous shale lithofacies; C-2: mixed calcareous shale lithofacies; C-3: clay-rich calcareous shale lithofacies; M: mixed shale lithofacies; M-1: calcareous/siliceous mixed-shale lithofacies; M-2: argillaceous/siliceous mixed-shale lithofacies: M-3: argillaceous/calcareous mixed-shale lithofacies. 


\subsubsection{Isothermal Adsorption Characteristics}

Ten core samples of Xinkailing-formation shale were obtained in the Wuning area to perform isothermal adsorption testing under conditions of $30^{\circ} \mathrm{C}$ and pure methane equilibrium humidity. The experimental data demonstrated that the saturated adsorption volume $V_{L}$ ranges from $2.12 \mathrm{~m}^{3} / \mathrm{t}$ to $3.47 \mathrm{~m}^{3} / \mathrm{t}$, with an average value of $2.50 \mathrm{~m}^{3} / \mathrm{t}$, and the Langmuir pressure $\mathrm{P}_{\mathrm{L}}$ ranges from 1.55 to $2.35 \mathrm{MPa}$ (average: 1.86 MPa) (as shown in Figure 11). Adsorption volume was found to increase as the pressure increased, and all the adsorption volumes were greater than $2 \mathrm{~m}^{3} / \mathrm{t}$. Consequently, Xinkailing-formation shale has strong adsorption capacity and can absorb more natural gas in situ with reservoir pressure. In addition, the adsorption capacity of Xinkailing-formation shale has a clear positive correlation with the total carbon content (as shown in Figure 12). The richer the organic matter, the higher the shale-adsorption capacity. Previous studies have concluded that gas adsorption volume first increases and then decreases as organic maturity increases [45]. Tests of organic matter maturity and gas-adsorption volume reveal that the adsorption volume of Xinkailing formation shale has a clear negative correlation with $R_{o}$ and that adsorption volume decreases with increasing organic matter maturity when the $R_{o}$ ranges from $2.8 \%$ to $3.2 \%$ (as shown in Figure 13 ).

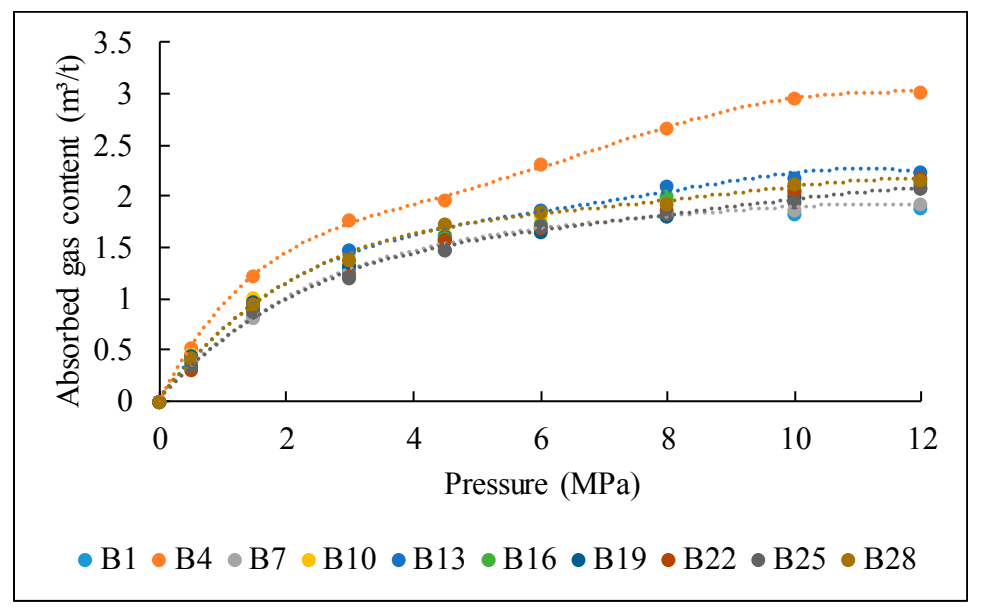

Figure 11. The isothermal adsorption characteristics of the Xinkailing formation in Wuning, related to pressure.

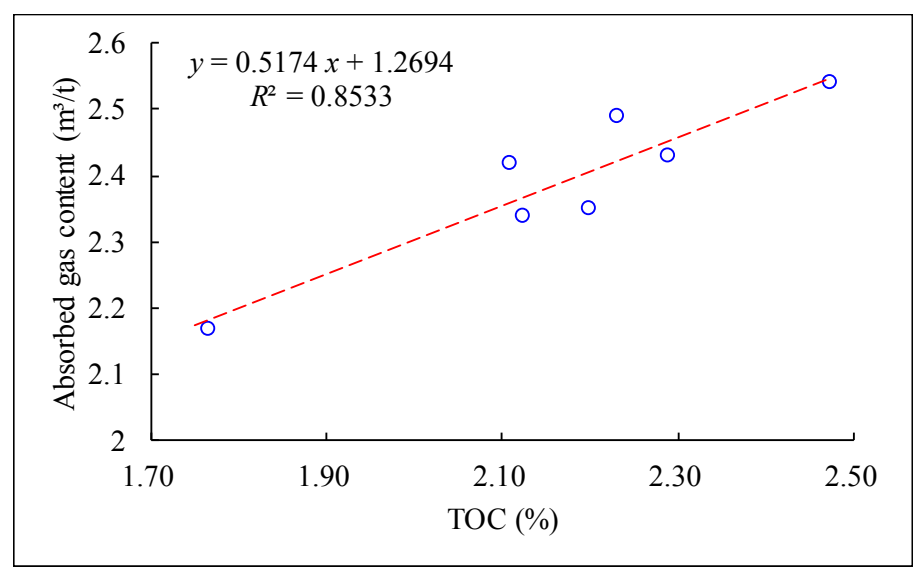

Figure 12. Positive relationship between total organic carbon (TOC) content and adsorbed gas content of Xinkailing shale. 


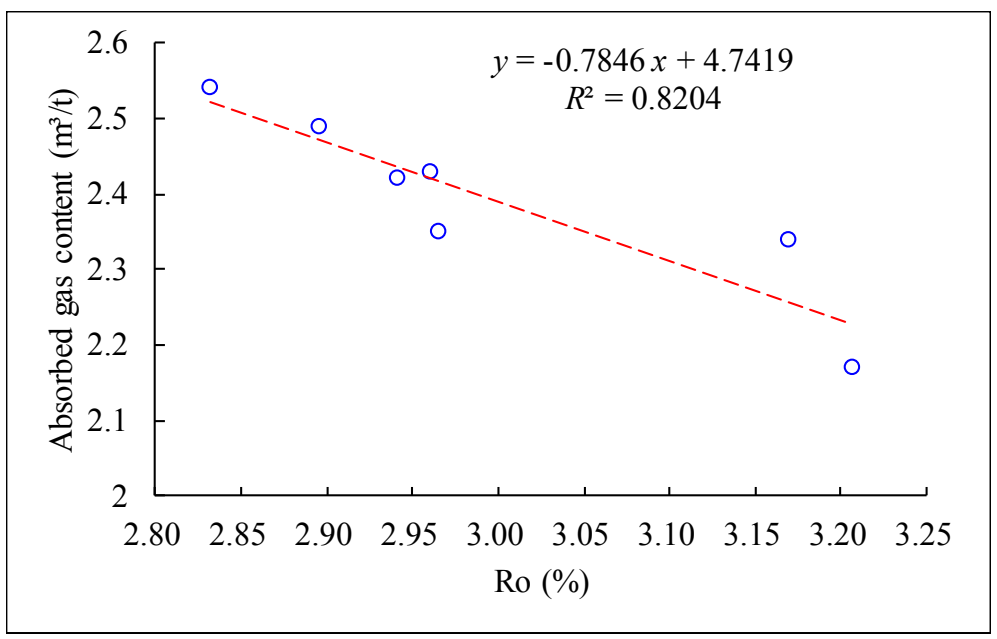

Figure 13. Negative relationship between vitrinite reflectance $\left(R_{o}\right)$ and adsorbed gas content of Xinkailing shale.

Based on the above analyses, it can be concluded that Xinkailing-formation shale in the Wuning area is characterized by low porosity and permeability, abundant reservoir space type, high brittle-minerals content, and excellent adsorption capacity, which are reservoir conditions that have excellent potential for shale-gas accumulation and development. Comparisons between Xinkailing-formation black shale in the Wuning area and Lower Silurian Longmaxi-formation shale in the middle-upper Yangtze were also conducted (as shown in Table 2), and results show that Xinkailing-formation shale has very good capacity to preserve shale gas with similar characteristics.

Table 2. Comparison of the reservoir parameters between the Xinkailing-formation shale in Wuning and the Lower Paleozoic-formation shale in the middle-upper Yangtze area.

\begin{tabular}{|c|c|c|c|c|c|c|c|c|}
\hline Area & Formation & $\begin{array}{l}\text { Porosity } \\
(\%)\end{array}$ & $\begin{array}{l}\text { Permeability } \\
\text { (md) }\end{array}$ & $\begin{array}{c}\text { Reservoir } \\
\text { Space Type }\end{array}$ & Pore Size & $\begin{array}{c}\text { Brittle } \\
\text { Mineral } \\
(\%)\end{array}$ & Lithofacies & $\begin{array}{c}\text { Isothermal } \\
\text { Adsorption } \\
\text { Volume } \\
\left(\mathrm{m}^{3} / \mathrm{t}\right)\end{array}$ \\
\hline Wuning & Xinkailing & $\begin{array}{c}1.10 \sim 1.22 / \\
1.16\end{array}$ & $\begin{array}{c}0.000445 \sim \\
0.001297\end{array}$ & $\begin{array}{l}\text { Organic pores } \\
\text { Net-shaped } \\
\text { fractures }\end{array}$ & $\begin{array}{c}\text { Meso pores } \\
\text { and Macro } \\
\text { pores }\end{array}$ & $51.6 \sim 56.06$ & $\begin{array}{c}\text { Clay-rich } \\
\text { siliceous shale }\end{array}$ & $2.12 \sim 3.47 / 2.5$ \\
\hline Fuling & Longmaxi & $\begin{array}{c}1.17 \sim 7.98 / \\
4.8\end{array}$ & $\begin{array}{c}0.0038 \sim \\
0.9813\end{array}$ & $\begin{array}{l}\text { Organic pores } \\
\text { Net-shaped } \\
\text { fractures }\end{array}$ & Meso pores & $62.42 \sim 64.76$ & $\begin{array}{c}\text { Mixed } \\
\text { siliceous shale } \\
\text { Clay-rich } \\
\text { siliceous shale }\end{array}$ & $0.98 \sim 6.89 / 3$ \\
\hline
\end{tabular}

\section{Discussion}

\subsection{The Xinkailing Shale Gas-Bearing Potential}

As many scholars have noted $[9,17,30,46]$, high-quality shale thickness, TOC, $R_{o}$, quartz content, and absorbed gas content have become the crucial parameters influencing the generation and development of shale gas. Accordingly, these five key parameters were chosen to quantitatively evaluate the Xinkailing shale gas-bearing potential. While the thickness of the black shale found in Wuning is lower than in three other areas (as shown in Figure 14), the TOC average is over $2 \%$, the $R_{o}$ ranges from $2.5 \%$ to $3.0 \%$, the quartz content is approximately $40 \%$, and the absorbed gas content is more than $2 \mathrm{~m}^{3} / \mathrm{t}$ in all four areas. Although only $18 \mathrm{~m}$ (the actual thickness could be found to be far more than that by drilling) of black shale were obtained from the water well, the characteristic parameters of Xinkailing shale in the study area are advantageous when compared with the Longmaxi shale in the Zhaotong, Pengshui, and Fuling areas, as well as the Upper Yangtze Platform, which underscores its gas-bearing capacity. If geological research drilling were undertaken, it is likely that more than $18 \mathrm{~m}$ of black, organic-rich shale would be discovered, also making a breakthrough for the gas-bearing content. 

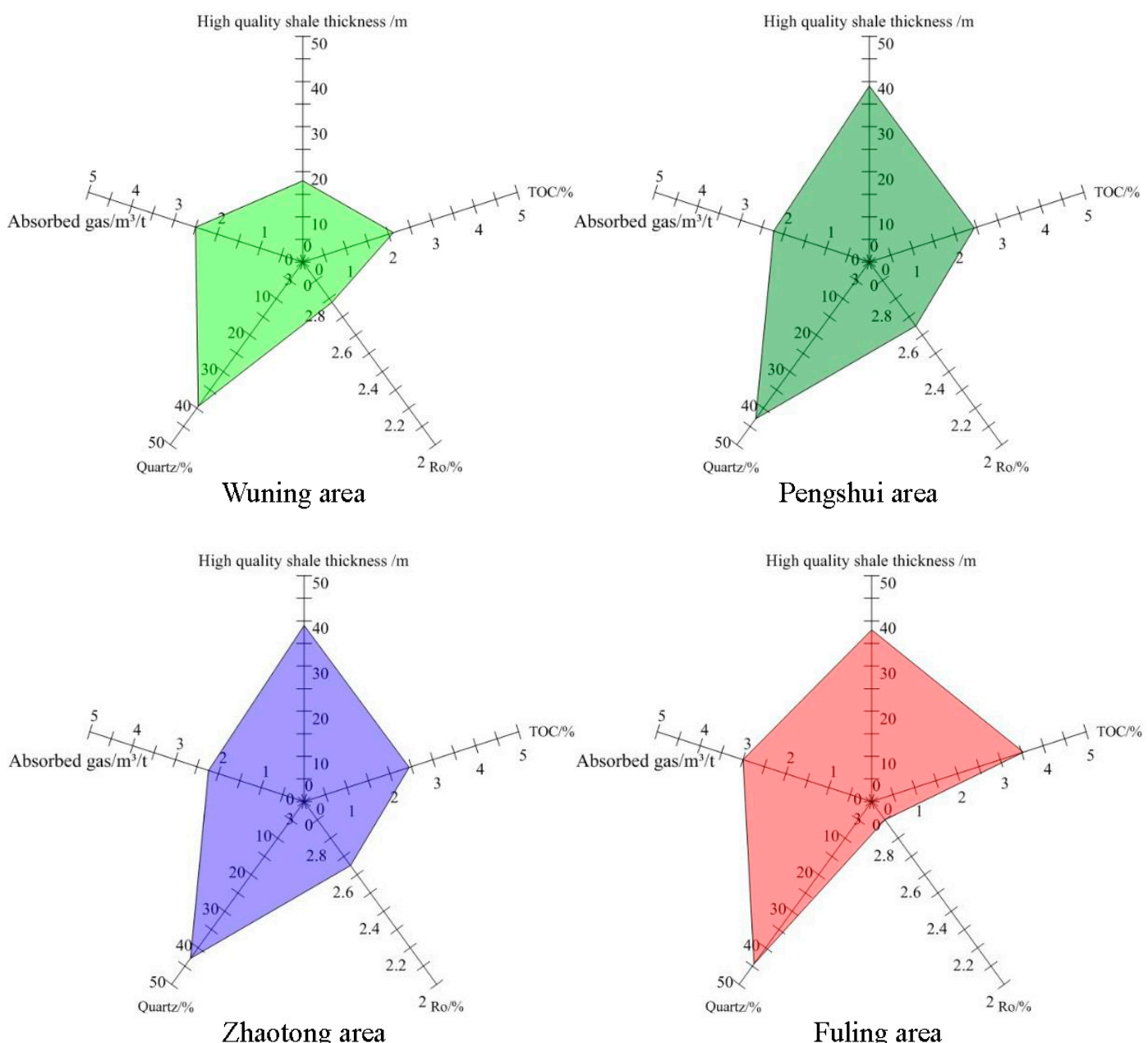

Figure 14. Comparison of the key shale-gas parameters between the Xinkailing-formation shale in Wuning and the Longmaxi shale in the middle-upper Yangtze area.

\subsection{The Optimization of Favorable Areas}

A multi-factor superposition method was adopted to identify favorable areas for shale-gas production. Referring to the shale-gas target area screening index for the marine shale in south China [47], seven parameters, including the thickness of organic-rich shale, sub-surface depth, organic carbon content, organic-matter maturity, reservoir conditions, brittle-minerals content and surface geomorphic conditions, were selected to evaluate favorable areas (as shown in Figure 15).

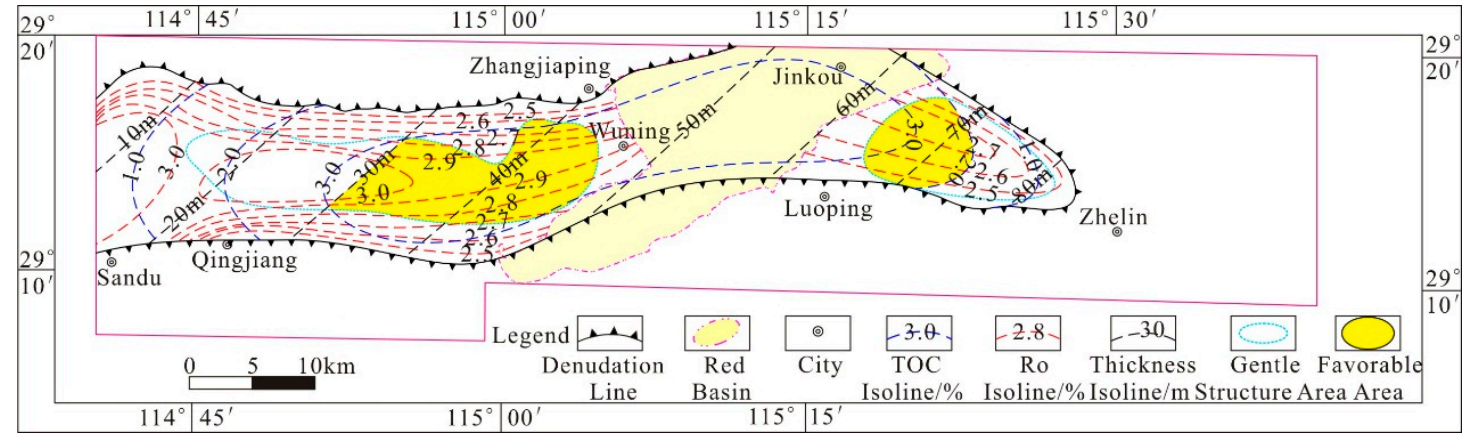

Figure 15. The optimization of favorable shale-gas areas for the Xinkailing formation in Wuning district. 
(1) Previous research has clarified that the key factors for the accumulation of shale gas are the thickness and sub-surface depth of organic-rich shale [47]. Organic-rich shale must be thick enough to form effective source rocks and reservoirs. Sub-surface depth not only has a significant effect on the production and accumulation of shale gas, but also directly impacts shale-gas development costs. The proper conditions of sub-surface depth with moderate temperature and pressure can trigger shale to generate hydrocarbons (including biogenic gas and thermogenic gas). It is unfavorable to accumulate free gas at greater sub-surface depths because large depth leads to greater pressure, in turn leading to smaller porosity. In the Wuning area, research results showed that the thickness of organic-rich shale increased from west towards east, ranging from $10 \mathrm{~m}$ to $80 \mathrm{~m}$. The sub-surface depth of the syncline wings was shallower than at the core of the syncline. The lower limit of thickness was determined to be $30 \mathrm{~m}$ during the process of optimizing favorable areas. The sub-surface depth of the Xinkailing formation in the whole area ranged from $500 \mathrm{~m}$ to $3000 \mathrm{~m}$, which was a favorable depth overall.

(2) TOC is a significant influencing factor of hydrocarbon-generating intensity, which determines the hydrocarbon-generating quantity [48] and plays an important role in the control of shale-gas accumulation. In addition, TOC also has a significant effect on shale gas by preserving gas due to the solution and adsorption effects (Figure 12). In Wuning, the overall TOC was greater than $1 \%$. TOC appeared to be higher in the middle of the area, but decreased toward the two sides. The lower limit of TOC was determined to be $2 \%$ during the process of optimizing favorable areas.

(3) In thermogenic shale-gas reservoirs, hydrocarbons are generated by the interaction of time, temperature and pressure. Kerogen maturity could not only predict hydrocarbon-generating potential, but also influences adsorption gas volume (Figure 13). In Wuning, the degree of thermal evolution showed a trend of "west high, east low" and "core high, side low". The upper limit of organic matter maturity was determined to be $3 \%$ during favorable-area optimization.

(4) Brittle-mineral content is a key parameter influencing the effect of hydraulic fracturing treatment [17]. In Wuning, the brittle-mineral content of Xinkailing-formation shale ranges from $51 \%$ to $64 \%$ (average $56.06 \%$ ) which can make the shale easily fractured.

(5) Preservation conditions also exert significant effects on the accumulation of shale gas [16], which are determined by the intensity of tectonic movement. To determine the shale-gas resources potential and exploitation direction it is important to comprehensively analyze reservoir-preservation conditions. The optimization of structurally favorable areas within the Xinkailing formation in Wuning was conducted under consideration of tectonic location, attitude of stratum (direction and angle of dip), distance from outcrops to the target layer, and the development of fractures. The optimization results showed that syncline cores are favorable areas for shale-gas accumulation due to their greater distance from the target layer outcrop, gentle dip angle, and poor fault development.

Based on the discussion above, the conclusion may reasonably be arrived at that it is reliable to use those key parameters to optimize favorable areas and effectively guide shale-gas reservoir exploration and exploitation that include organic-rich shale thickness, buried depth, TOC, brittle-mineral content and preservation conditions. By comprehensively analyzing the elements, gas accumulation in Xinkailing-formation shale in Wuning had mainly developed in the Wuning-Lixi and Jinkou-Zhelin areas (Figure 15). The thickness of organic-rich shale ranged from $10 \mathrm{~m}$ to $80 \mathrm{~m}$, TOC was relatively high (greater than $2 \%$, overall), and Ro ranged from $2.5 \%$ to $3.0 \%$ in the over-mature stage, all of which are conditions for excellent gas-bearing potential. Organic-rich shale was well developed and had good preservation conditions, which indicate good potential for shale-gas development and exploitation.

\section{Conclusions}

To better understand the characteristics of Xinkailing-formation shale and shale-gas accumulation conditions in the Wuning area, abundant work has been conducted and relevant data has been 
gathered. The shale of the Xinkailing formation differs greatly between core samples and outcrop samples. The outcrop profile confirms that the shale is very thick with severe weathering, while analysis of the water well revealed high-quality shale deposited under stable, anoxic deep-water sediment. Geochemical analysis (organic matter type, TOC, and $R_{o}$ ) suggests that the Xinkailing shale obtained from the water well acts as a good source rock and has considerable shale-gas resource potential. Pores (cracks) between clay minerals, intergranular dissolution pores, pores between minerals, organic matter pores, and interlaminated fractures and structural fractures can be identified in the Xinkailing shale, among which the organic pores, pores (cracks) between clay minerals, and fractures may provide the main storage space. The pore sizes are mainly predominated by meso-pores $(2-50 \mathrm{~nm})$ and macro-pores $(>50 \mathrm{~nm})$. Compared with the Longmaxi shale in the middle-upper Yangtze area, it can be concluded that Xinkailing shale possesses advantageous shale-gas accumulation conditions. By selecting such key parameters, including organic-rich shale thickness (more than $30 \mathrm{~m}$ ), sub-surface depth (more than $500 \mathrm{~m}$ and less than $3000 \mathrm{~m}$ ), TOC content (over $2 \%$ ), thermal evolution degree (more than $2 \%$ and less than $3 \%$ ), preservation condition (poor fault development nearby), and geomorphologic factors (flat), the Wuning-Lixi and Jinkou-Zhelin favorable areas are optimized, and additional shale-gas breakthroughs could be discovered in the Lower Yangtze area through drilling.

Acknowledgments: The work presented in this paper was supported by the National Shale Gas Resource Potential and Favorable Areas Project (Grant No. 2009GYXQ15-06-05) and Jiangxi Province Science and Technology Major Project (Grant No. 20152ACE50014). We are grateful to Tang Zhaoyou, Cao Haifeng, Xiongkuan and others for their help with the fieldwork.

Author Contributions: These authors contributed equally to this work.

Conflicts of Interest: The authors declare no conflict of interest.

\section{References}

1. Curtis, J.B. Fractured shale-gas systems. AAPG Bull. 2002, 86, 1921-1938.

2. Montgomery, S.L.; Jarvie, D.M.; Bowker, K.A. Mississippian Barnett Shale, Fort Worth basin, north-central Texas: Gas-shale play with multi-trillion cubic foot potential. AAPG Bull. 2005, 89, 155-175. [CrossRef]

3. Bowker, K.A. Barnett Shale gas production, Fort Worth Basin: Issues and discussion. AAPG Bull. 2007, 91, 523-533. [CrossRef]

4. Tang, X.L.; Jiang, Z.X.; Li, Z. The effect of the variation in material composition on the heterogeneous pore structure of high-maturity shale of the Silurian Longmaxi formation in the southeastern Sichuan Basin, China. J. Nat. Gas Sci. Eng. 2015, 23, 464-473. [CrossRef]

5. Zhou, D.S.; Xu, L.F.; Pan, J.P. Prospect of shale gas exploration in the Upper Permian Longtan Formation in the Yangtze Massif. Nat. Gas Ind. 2012, 32, 6-10.

6. Yang, F.; Ning, Z.F.; Liu, H.Q. Fractal characteristics of shales from a shale gas reservoir in the Sichuan Basin, China. Fuel 2014, 115, 378-384. [CrossRef]

7. Liu, X.J.; Xiong, J.; Liang, L.X. Investigation of pore structure and fractal characteristics of organic-rich Yanchang formation shale in central China by nitrogen adsorption/desorption analysis. J. Nat. Gas Sci. Eng. 2015, 22, 62-72. [CrossRef]

8. Li, P.; Jiang, Z.X.; Zheng, M. Estimation of shale gas adsorption capacity of the Longmaxi Formation in the Upper Yangtze Platform, China. J. Nat. Gas Sci. Eng. 2016, 34, 1034-1043. [CrossRef]

9. Guo, T.L.; Zhang, H.R. Formation and enrichment mode of Jiaoshiba shale gas field, Sichuan Basin. Pet. Explor. Dev. 2014, 41, 31-40. [CrossRef]

10. Zhang, J.C.; Yang, C.; Chen, Q. Deposition and distribution of potential shales in China. Earth Sci. Front. 2016, 23, 74-86.

11. Liang, D.G.; Guo, T.L.; Bian, L.Z. Some progress on studies of hydrocarbon generation and accumulation in marine sedimentary regions, southern China (Part 3): Controlling factors on the sedimentary facies and development of Paleozoic marine source rocks. Mar. Orig. Pet. Geol. 2009, 14, 1-19.

12. Liang, D.G.; Guo, T.L.; Chen, J.P. Some progress on studies of hydrocarbon generation and accumulation in marine sedimentary regions, southern China. (Part 1): Distribution of four suits of regional marine source rocks. Mar. Orig. Pet. Geol. 2008, 13, 1-16. 
13. Liang, D.G.; Guo, T.L.; Chen, J.P. Some progress on studies of hydrocarbon generation and accumulation in marine sedimentary regions, southern China. (Part 2): Geochemical characteristics of four suits of regional marine source rocks, south China. Mar. Orig. Pet. Geol. 2009, 14, 1-15.

14. Liang, C.; Jiang, Z.X.; Zhang, C.M. The shale characteristics and shale gas exploration prospects of the Lower Silurian Longmaxi shale, Sichuan Basin, South China. J. Nat. Gas Sci. Eng. 2014, 21, 636-648. [CrossRef]

15. Tan, J.Q.; Horsfield, B.; Fink, R. Shale Gas Potential of the Major Marine Shale Formations in the Upper Yangtze Platform, South China, Part III: Mineralogical, Lithofacial, Petrophysical and Rock Mechanical Properties. Energy Fuels 2014, 28, 2322-2342. [CrossRef]

16. Wang, R.Y.; Ding, W.L.; Gong, D.J. Gas preservation conditions of marine shale in northern Guizhou area: A case study of the Lower Cambrian Niutitang Formation in the Cen'gong block, Guizhou Province. Oil Gas Geol. 2016, 37, 45-55.

17. Jin, Z.J.; Hu, Z.Q.; Gao, B. Controlling factors on the enrichment and high productivity of shale gas in the Wufeng-Longmaxi Formations, southeastern Sichuan Basin. Earth Sci. Front. 2016, 23, 1-10.

18. Tuo, J.C.; Wu, C.J.; Zhang, M.F. Organic matter properties and shale gas potential of Paleozoic shales in Sichuan Basin, China. J. Nat. Gas Sci. Eng. 2016, 28, 434-446. [CrossRef]

19. Guo, X.S.; Hu, D.F.; Wen, Z.D. Major factors controlling the accumulation and high productivity in marine shale gas in the Lower Paleozoic of Sichuan Basin and its periphery: A case study of the Wufeng-Longmaxi Formation of Jiaoshiba area. Geol. China 2014, 41, 893-901.

20. Guo, T.L. Discovery and characteristics of the Fuling shale gas field and its enlightenment and thinking. Earth Sci. Front. 2016, 23, 29-43.

21. Cai, Z.R.; Xia, B.; Huang, Q.T. Comparative study of the tectonic setting on the formation and preservation of Paleozoic shale gas between the Upper Yangtze and the Lower Yangtze platforms. Nat. Gas Geosci. 2015, 26, 1446-1454.

22. Pang, F.; Bao, S.J.; Ren, S.M. Shale gas accumulation conditions and favorable areas of the lower Cambrian in Xiuwu basin. J. Northeast Pet. Univ. 2014, 38, 23-30.

23. Liu, W.W.; Tian, J.C.; Lin, X.B. Characteristics and significance of mineral compositions in Lower Cambrian black shale from Xiuwu basin, Jiangxi, China. J. Chengdu Univ. Technol. Sci. Technol. Ed. 2015, 42, 90-97.

24. Huang, X.B. Basic features of decollement structures in the Xiushui-Yongxiu area of northwest Jiangxi. Jiangxi Geol. 2001, 15, 81-86.

25. Mort, H.P.; Adatte, T.; Keller, G. Organic carbon deposition and phosphorus accumulation during Oceanic Anoxic Event 2 in Tarfaya, Morocco. Cretac. Res. 2008, 29, 1008-1023. [CrossRef]

26. Hemmesch, N.T.; Harris, N.B.; Mnich, C.A. A sequence stratigraphic framework for the Upper Devonian Woodford Shale, Permian Basin, west Texas. AAPG Bull. 2014, 98, 23-47. [CrossRef]

27. Feng, G.X.; Chen, S.J. Relationship between the reflectance of bitumen and vitrinite in rock. Nat. Gas Ind. 1988, 8, 20-25.

28. Qin, J.Z.; Li, Z.M.; Teng, G.E. A study paleo-geothermometer of high mature marine sequences in South China. Oil Gas Geol. 2009, 30, 608-618.

29. Zhang, J.C.; Lin, L.M.; Li, Y.X. The method of shale gas assessment: Probability volume method. Earth Sci. Front. 2012, 19, 184-191.

30. Jarvie, D.M.; Hill, R.J.; Ruble, T.E. Unconventional shale-gas systems: The Mississippian Barnett Shale of north-central Texas as one model for thermogenic shale-gas assessment. AAPG Bull. 2007, 91, 475-499. [CrossRef]

31. Cardott, B.J. Thermal maturity of Woodford Shale gas and oil plays, Oklahoma, USA. Int. J. Coal Geol. 2012, 103, 109-119. [CrossRef]

32. Huang, J.L.; Zou, C.N.; Li, J.Z. Shale gas generation and potential of the Lower Cambrian Qiongzhusi Formation in Southern Sichuan Basin, China. Pet. Explor. Dev. 2012, 39, 69-75. [CrossRef]

33. Xie, D.; Xu, T.J.; Zhang, W.K. Organic geochemical characteristics of Qiongzhusi Formation in Jingyan-Qianwei area. Nat. Gas Technol. Econ. 2015, 9, 1-4.

34. Jiang, Y.Q.; Song, Y.T.; Qi, L. Fine lithofacies of China's marine shale and its logging prediction: A case study of the Lower Silurian Longmaxi marine shale in Weiyuan area, southern Sichuan Basin, China. Earth Sci. Front. 2016, 23, 107-118.

35. Nie, H.K.; Zhang, J.C. Research on types and characteristics of shale gas reservoir: A case study of Lower Paleozoic in and around Sichuan Basin. Pet. Geol. Exp. 2011, 33, 219-225. 
36. Slatt, R.M.; Brien, N.R.O. Pore types in the Barnett and Woodford gas shales: Contribution to understanding gas storage and migration pathways in fine-grained rocks. AAPG Bull. 2011, 95, 2017-2030. [CrossRef]

37. Zeng, L.B.; Lyu, W.Y.; Li, J. Natural fractures and their influence on shale gas enrichment in Sichuan Basin, China. J. Nat. Gas Sci. Eng. 2016, 30, 1-9. [CrossRef]

38. Ross, D.J.K.; Bustin, R.M. The importance of shale composition and pore structure upon gas storage potential of shale gas reservoirs. Mar. Pet. Geol. 2009, 26, 916-927. [CrossRef]

39. Hu, Z.Q.; Du, W.; Peng, Y.M. Microscopic pore characteristics and the source-reservoir relationship of shale-A case study from the Wufeng and Longmaxi Formations in Southeast Sichuan Basin. Oil Gas Geol. 2015, 36, 1001-1008.

40. Sing, K.S.W. Reporting physisorption data for gas/solid systems with special reference to the determination of surface area and porosity (Recommendations 1984). Pure Appl. Chem. 1982, 54, 2201-2218. [CrossRef]

41. Rouquerol, J.; Avnir, D.; Everett, D.H. Guidelines for the Characterization of Porous Solids. Pure Appl. Chem. 2014, 87, 1-9.

42. Clarkson, C.R.; Solano, N.; Bustin, R.M. Pore structure characterization of North American shale gas reservoirs using USANS/SANS, gas adsorption, and mercury intrusion. Fuel 2013, 103, 606-616. [CrossRef]

43. Lin, B.T.; Chen, M.; Jin, Y. Modeling pore size distribution of southern Sichuan shale gas reservoirs. J. Nat. Gas Sci. Eng. 2015, 26, 883-894. [CrossRef]

44. Wu, L.Y.; Hu, D.F.; Lu, Y.C. Advantageous shale lithofacies of Wufeng Formation-Longmaxi Formation in Fuling gas field of Sichuan Basin, SW China. Pet. Explor. Dev. 2016, 43, 208-217. [CrossRef]

45. Chen, K.; Zhang, J.C.; Tang, X. Main controlling factors on shale adsorption capacity of the Lower Silurian Longmaxi Formation in western Hunan-Hubei area. Oil Gas Geol. 2016, 37, $23-29$.

46. Ross, D.J.K.; Bustin, R.M. Characterizing the shale gas resource potential of Devonian-Mississippian strata in the Western Canada sedimentary basin: Application of an integrated formation evaluation. AAPG Bull. 2008, 92, 87-125. [CrossRef]

47. Liu, H.L.; Wang, H.Y.; Fang, C.H. The formation mechanism of over-pressure reservoir and target screening index of the marine shale in the South China. Earth Sci. Front. 2016, 23, 48-54.

48. Wang, Z.P.; Zhang, J.C.; Sun, R. The gas-bearing characteristics analysis of the Longtan Formation transitional shale in Well Xiye 1. Earth Sci. Front. 2015, 22, 243-250.

(C) 2017 by the authors. Licensee MDPI, Basel, Switzerland. This article is an open access article distributed under the terms and conditions of the Creative Commons Attribution (CC BY) license (http:/ / creativecommons.org/licenses/by/4.0/). 